\title{
ANALISIS YURIDIS BATALNYA PERJANJIAN PRA- NIKAH DALAM PERKAWINAN
}

\section{CAMPURAN (Putusan Perkara No: 526/PDT/G/2012/PN.JKT.SEL)}

\author{
Ayu Natashasia Sembiring1) ,Agus Kristianto Sinaga'2), Satria Braja Hariandja.33 \\ 1,2,3) Mahasiswa dan Dosen Fakultas Hukum Universitas Prima Indonesia \\ E-mail : yunasembirings@gmail.com 1, Agusk174@gmail.com.²
}

\begin{abstract}
Mixed marriages according to Law Number 1 of 1974 concerning marriage are marriages between Indonesian citizens and foreign nationals (Article 57). Because of different nationalities, the laws applied to them are also different. Marriage Law does not expressly regulate the legal consequences arising from Mixed marriages. According to the Marriage Law of citizenship which is obtained as a marriage result, marital disturbances determine the applicable law, about public law and civil law.This research is a normative legal research that is prescriptive with a legislative approach and a conceptual approach. The sources and types of legal materials used are primary legal materials that are supported by secondary legal materials. Pre-Marriage Agreement Research Results is not implemented in good faith by each party that makes a prenuptial agreement so that it is null and void.
\end{abstract}

Keywords: Pre-Marriage Agreement, Mixed Marriage, Marriage Law

\section{PENDAHULUAN}

\section{A. Latar Belakang}

Dalam Pasal 1 Undang-Undang Nomor 1 Tahun 1974 tentang Perkawinan menyatakan: "Ikatan lahir dan bahtin antara seseorang pria dan wanita sebgai suami isteri dengan tujuan untuk membentuk keluarga yang bahagia dan kekal berdasarkan Ketuhanan Yang Maha Esa". Dasar-dasar perkawinan dibentuk oleh unsure-unsur alami dari kehidupan manusia itu sendiri meliputi kebutuhan dan fungsi biologis, melahirkan keturunan, kebutuhan akan kasih saying dan persaudaraan, memelihara anak-anak tersebut menjadi anggota-anggota masyarakat yang sempurna.Pengaturan hukum tentang perkawinan telah berlaku sama terhadap semua warga Negara oleh karena itu, setiap warga Negara harus patuh terhadap hukum yang berlaku, termasuk terhadap
Undang-Undang Perkawinan yang menjadi landasan untuk menciptakan kepastian hukum dari suatu perkawinan. Hal ini sesuai dengan Pasal 2 Undang-Undang Nomor 1 Tahun 1974 tentang Perkawinan, menyatakan:

a. Perkawinan adalah sah, apabila dilakukan menurut hokum masing-masing agamanya dan kepercayaannya itu.

b. Tiap-tiap perkawinan dicacat menurut peraturan perundangundangan yang berlaku.

Hal ini juga berlaku dalam perkawinan, dimana adanya ikatan pria dan wanita ini juga dapat dilakukan oleh pria dan wanita yang berbeda kewarganegaraan, yang lebih dikenal dengan perkawinan campuran.Perkawinan campuran di Indonesia dilakukan berdasarkan Undang-Undang Nomor 1 tahun 1974 tentang Perkawinan. Berdasarkan Pasal 
57 Undang-Undang Nomor 1 Tahun 1974 tentang Perkawinan, menyatakan: "Perkawinan campuran adalah perkawinan antara dua orang yang ada di Indonesia dan tunduk pada hukum yang berlainan karena perbedaan kewarganegaraan serta salah satu pihak berkewarganegaraan Indonesia.

Hal ini diatur dalam Pasal 59 ayat (2) Undang-Undang Nomor 1 tahun 1974 tentang Perkawinan, menyatakan: "Perkawinan campuran yang dilangsungkan di Indonesia dilakukan menurut Undang-Undang ini". Perkawinan campuran tidak dapat dilaksanakan sebelum terbukti syaratsyarat perkawinan dipenuhi, menurut hukum yang berlaku bagi masingmasing, oleh mereka yang berwenang mencatat perkawinan diberi Surat Keterangan bahwa syarat-syarat tersebut telah dipenuhi.Dengan demikian tidak ada masalah untuk melangsungkan perkawinan campuran.

Mengenai perkawinan campuran yang dilakukan di Indonesia harus sesuai dengan Pasal 56 Undang-Undang Nomor 1 tahun 1974 tentang Perkawinan, menyatakan:

1) Perkawinan di Indonesia antara dua orang warga Negara Indonesia (WNI) atau seorang warga Negara Indonesia (WNI) dengan warga Negara Asing (WNA) adalah sah bilamana dilakukan menurut hokum yang berlaku di Negara dimana perkawinan itu dilangsungkan dan bagi warga Negara Indonesia tidak melanggar ketentuan Undang-Undang ini.

2) Dalam waktu 1 (satu) tahun setelah suami isteri itu kembali ke Indonesia, surat bukti perkawinan mereka harus didaftarkan pada kantor pencatatan perkawinan setempat.
Akibat hukum yang ditimbulkan oleh perkawinan amat penting, tidak saja dalam hubungan dengan kekeluargaan, tetapi juga dalam bidang harta kekayaannya.Hukum kekayaan (harta kekayaan) dalam sistematika hukum perdata menurut ilmu hukum pada buku kesatu.Hubungan hukum yang dapat dinilai dengan uang, diatur dalam hukum kekayaan. Jika kita mengatakan tentang kekayaan seseorang, yang dimaksud ialah jumlah segala hak dan kewajiban orang itu, dinilai dengan uang.

Umumnya setiap orang yang akan menikah menginginkan keluarga yang bahagia dan kekal, namun dalam kenyataan perjalanan sebuah perkawinan tidak selalu mulus ada kemungkinan timbul masalah-masalah yang akan mereka hadapi antara lain mengenai anak, kewarganegaraan karena mereka tunduk pada hukum yang berlainan, dan juga harta kekayaan yang diperoleh selama perkawinan.

Harta bersama ini merupakan gabungan harta suami dan isteri semenjak perkawinan. Hal ini diatur dalam Pasal 119 KUH Perdata, menyatakan: "Mulai saat perkawinan dilangsungkan demi hukum berlakulah persatuan bulat harta kekayaan suami isteri, sekedar mengenai itu tidak diadakan perjanjian perkawinan atau ketentuan lain. Persatuan itu sepanjang perkawinan tidak boleh ditiadakan atau diubah dengan sesuatu persetujuan suami dan isteri.

Ketentuan Pasal 119 KUH Perdata berlaku bagi WNI yang tidak beragama Islam, sedangkan bagi orang yang beragama Islam berlaku Kompilasi Hukum Islam.Jadi semua harta yang diperoleh selama perkawinan berlangsung merupakan harta bersama antara WNI dan WNA. Menurut Subekti, harta bersama yang diatur dalam Undang-Undang Nomor 1 Tahun 1974 tentang Perkawinan didasarkan pola 
hukum adat. Dalam hukum adat, harta perkawinan lazimnya dapat dipisahkan dalam 4 (empat) golongan, sebagai berikut:

a) Barang-barang yang diperoleh suami atau isteri secara warisan atau penghibahan dari kerabat (family) masing-masing dan dibawa kedalam perkawinan

b) Barang-barang yang diperoleh suami atau isteri untuk diri sendiri serta atas jasa diri sendiri sebelum perkawinan atau dalam masa perkawinan.

c) Barang-barang yang dalam masa perkawinan diperoleh suami isteri sebagai milik bersama

d) Barang-barang yang dihadiahkan kepada suami isteri bersama pada waktu pernikahan.

Harta bersama dalam perkawinan di atur dalam Pasal 35 Undang-Undang Nomor 1 Tahun 1974 tentang Perkawinan, menyatakan:

1) Harta benda yang diperoleh selama perkawinan menjadi harta bersama

2) Harta bawaan dari masingmasing suami dan isteri dan harta benda yang diperoleh masing-masingsebagai hadiah atau warisan, adalah dibawah penguasaan masing-masing sepanjang para pihak tidak menentukan lain.

Berdasarkan Pasal diatas, maka harta benda dalam perkawinan dibedakan menjadi 2 (dua) macam yaitu:

a. Harta Bersama

Harta bersama adalah harta benda yang diperoleh selama perkawinan, tanpa dipersoalkan asalnya baik yang diperoleh oleh suami maupun isteri, semuanya merupakan harta milik bersama suami isteri.

b. Harta Bawaan
Harta bawaan adalah harta yang dibawa masuk oleh masing-masing suami isteri kedalam perkawinan.Contoh harta bawaan adalah hadiah dan warisan.

Berdasarkan hal-hal tersebut diatas, maka peneliti tertarik untuk melakukan penelitian dan mengangkatnya ke dalam sebuah Jurnal yang berjudul “

\section{B. Rumusan Masalah}

Adapun rumusan masalah didalam penelitian ini sebagai berikut:

1. Bagaimakah kedudukan Harta Bersama Menurut hukum perjanjian perkawinan Campuran?

2. Bagaimanakah Akibat Hukum status harta yang diperoleh sebelum dan sesudah perkawinan campuran?

3. Bagaimanakah Dasar pertimbangan Majelis Hakim terhadap pembagian harta bersama setelah perceraian dalam Putusan Perkara Nomor : 526/Pdt.G/2012/PN.JKT.SEL?

\section{Metode Penelitian}

Jenis penelitian dalam jurnal ini adalah penelitian yuridis normatifempiris karena dasarnya merupakan penggabungan antara pendekatan hukum normatif dengan ada penambahan berbagai unsur empiris. Jenis penelitian normatif-empiris mengenai implementasi ketentuan hukum normatif (undang-undang) yang terjadi dalam penelitian kategori Judicial Case Study yang merupakan pendekatan studi kasus hukum karena konflik sehingga akan melibatkan campur tangan dengan pengadilan untuk memberikan keputusan penyelesaian (yurisprudensi). Bersifat deskriptif analitis yaitu dengan memaparkan dan menelaah sebelum dan sesudah pemisahan harta bersama melalui perkawinan pra-nikah dalam perceraian akibat perkawinan 
campuran melalui penetapan pengadilann, yang dihubungkan dengan peraturan perundang-undangan bertujuan untuk mempelajari suatu hukum dengan cara menganalisa putusan tersebut.

\section{HASIL DAN PEMBAHASAN}

\section{A. Kedudukan Harta Bersama Menurut hukum perjanjian perkawinan Campuran}

1. Kedudukan Harta Bersama Dalam perkawinan

Ikatan perkawinan menjadikan adanya harta bersama antara suami istri, sebagaimana tertuang dalam undang-undang perkawinan pasal 35 ayat (1).Namun, bukan berarti dalam perkawinan yang diakui hanya harta bersama sebab berdasarkan KHI pasal 85, yang juga ditegaskan oleh Ahmad Rofiq dalam bukunya yang berjudul Hukum Islam Di Indonesia, dinyatakan bahwa "meskipun terdapat harta bersama dalam perkawinan itu, dimungkinkan adanya hak milik tentang harta pribadi".

Harta perkawinan adalah semua harta yang dikuasai suami dan istri selama mereka terikat dalam perkawinan. Kebutuhan akan harta dalam perkawinan merupakan salah satu usaha untuk menciptakankeluarga yang sejahtera lahir dan batin. Harta perkawinan terdiri dari harta asal dan harta bersama.Kekayaan duniawi inilah yang disebut "harta perkawinan",

"harta keluarga" ataupun "harta bersama".

\section{Harta asal}

Harta asal adalah harta yang dimiliki dan dikuasai oleh suami atau istri secara pribadi sebelum dan/atau selama perkawinan.Suami atau istri mempunyai hak sepenuhnya untuk melakukan perbuatan hukum terhadap harta asal miliki masing-masing. Mereka bebas menentukan terhadap harta benda tersebut tanpa ikut campur suami atau istri untuk menjualnya, dihibahkan atau mengagunkannya.Harta asal terdiri dari:

2. Harta pribadi

Harta pribadi adalah harta benda milik masing-masing suami atau istri yang diperoleh atas usaha sendiri sebelum terjadinya perkawinan. Penguasaan harta pribadi yang dibawa kedalam perkawinan, tetap berada pada masing-masing suami atau istri, kecuali ditentukan lain dalam perjanjian.

3. Harta warisan

Harta warisan adalah harta atau barang-barang yang dimiliki oleh suami atau istri baik sebelum perkawinan ataupun setelah perkawinan, yang berasal dari harta warisan orang tua untuk dikuasai dan dimiliki secara perseorangan.Yurisprudensi Mahkamah Agung Republik Indonesia Nomor 562/K/Sip/1979 (Tasikmalaya, Bandung) hibah suami kepada istri mengenai harta warisan tidak dapat disahkan, karena ahli waris suami tersebut menjadi hilang hak warisnya.

4. Harta peninggalan

Harta peninggalan adalah harta atau barang-barang yang dikuasai oleh suami atau istri yang berasal dari peninggalan orang tua masing-masing untuk diteruskan penguasaan dan pengaturannya guna kepentingan para ahli waris bersama, dikarenakan harta peninggalan tersebut tidak terbagi-bagi kepada setiap ahli waris.Harta peninggalan tetap berada pada penguasaan masing-masing suami atau istri.

\section{Hibah}

Harta atau barang-barang yang dimiki suami atau istri yang diberikan seseorang secara cuma-cuma pada masa hidupnya. Hibah yang diperoleh suami atau istri sebelum perkawinan dan/atau setelah perkawinan berada pada penguasaan masing-masing, kecuali ditentukan lain dalam perjanjian.

6. Hadiah 
Harta atau barang-barang yang dimiliki suami atau istri yang berasal dari pemberian atau hadiah dari anggota kerabat ataupun orang lain. Hadiah yang diperoleh sebelum dan/atau setelah perkawinan, penguasaannya tetap berada pada masing-masing suami atau istri, kecuali ditentukan lain dalam perjanjian.

\section{Harta bersama}

Harta bersama adalah harta yang dimiliki atau diperoleh setelah dilangsungkannya perkawinan, dan menjadi hak bersama pasangan suamiistri.Harta bersama meliputi benda bergerak maupun benda tidak bergerak, benda berwujud dan tidak berwujud dan segala macam kekayaan lainnya yang dapatdinilai dengan uang.Hartabersama berarti harta yang dipergunakan (dimanfaatkan) bersamasama".Hukum tidak mempermasalahkan siapapun yang memperolehnya baik suami maupun istri, kecuali yang termasuk dalam harta asal.

Suami maupun istri dapat bertindak terhadap harta bersama atas persetujuan kedua belah pihak. Penggolongan jenis-jenis harta tersebut diatas memberikan konsekuensinya terdapat dua macam penggolongan hak milik terhadap harta yaitu:

a. Hak milik secara kolektif

Hak milik secara kolektif atau harta bersama khusus mengenai harta yang diperoleh atas hasil dari mata pencaharian bersama selama berlangsungnya perkawinan. Hukum tidak mempermasalahkan siapapun yang memperolehnya baik suami maupun istri,kecuali yang termasuk dalam harta asal. Dengan adanya hak kepemilikan secara kolektif ini tentunya wewenang dan tanggung jawab terhadap harta bersama tersebut berada di tangan suami dan istri.Apabila suami hendak menggunakan harta bersama maka suami harus mendapat persetujuan dari istri, demikian juga sebalikya.

b. Hak milik pribadi secara terpisah Hak milik pribadi secara terpisah, untuk jenis harta yang digolongkan dalam harta asal, penguasaannya pada dasarnya dilakukan secara terpisah.Masingmasing suami-istri mempunyai hak milik secara terpisah terhadap harta asal tersebut.Harta tersebut dapat menjadi harta kolektif dengan melihat ketentuan Pasal 35 ayat (2), pencampuran harta dapat dimungkinkan apabila ditentukan dalam perjanjian.

Pasal 91 KHI menegaskan bahwa:

1. Harta bersama sebagaimana tersebut dalam pasal 85 di atas dapat berupa benda berwujud atau tidak berwujud;

2. Harta bersama yang berwujud dapat meliputi benda tidak bergerak, benda bergerak dan surat-surat berharga;

3. Harta bersama yang tidak berwujud dapat berupa hak maupun kewajiban;

4. Harta bersama dapat dijadikan sebagai barang jaminan oleh salah satu pihak atas persetujuan pihak lainnya.

Hak dalam Pasal $91 \mathrm{KHI}$, menunjukan activa sedangkan kewajiban menunjukkanpassiva yaitu kewajiban membayar sejumlah hutang. KHI telah memasukkan semua passiva kedalam harta bersama, dengan demikian apabila terjadi perceraian antara suami-istri dan kemudian mereka berbagi harta bersama, yang dibagi tidak hanya berupa activa saja tetapi semua hutang dan kredit yang dibuat semasa perkawinan dan atas persetujuan bersama harusdimasukkan sebagai harta bersama yang bersifat passiva. 
Pasal 93 ayat (2), (3) dan (4) KHI menyatakan bahwa:

1. Pertanggungjawaban terhadap hutang yang dilakukan untuk kepentingan keluarga, dibebankan kepada harta bersama;

2. Bila harta bersama tidak mencukupi, dibebankan kepada harta suami;

3. Bila harta suami tidak ada atau mencukupi dibebankan kepada harta isteri.

2. Kedudukan Harta Bersama Setelah Perceraian

Harta bersama adalah harta benda yang diperoleh selama perkawinan, kecuali harta yang termasuk dalam harta asal. Berdasarkan peraturan Pasal 1 huruf (f) KHI menyebutkan bahwa, harta yang diperoleh sendiri maupun bersama selama perkawinan merupakan harta kekayaan dalam perkawinan, dan selanjutnya disebut sebagai harta bersama tanpa mempersoalkan terdaftar atau diperoleh atas nama siapapun, baik suami maupun istri.

Harta bersama merupakan salah satu hal yang diperebutkan antara suami-istri ketika terjadinya perceraian ataupun setelah perceraian. Akibat hukum perceraianterhadap harta bersama diatur dalam Pasal 37 UU No. 1 Tahun 1974 yaitu, bila perkawinan putus karena perceraian, harta bersama diatur menurut hukumnya masingmasing.Pembagian harta bersama dalam hukum Islam, diatur dalam Pasal 97 KHI yaitu, janda atau duda cerai hidup masing-masing berhak seperdua dari harta bersama sepanjang tidak ditentukan lain dalam perjanjian perkawinan.Namun, pada kenyataannya tidak selamanya harta bersama tersebut dibagi sama rata, yaitu masing-masing mendapatkan 50\%. Pembagian harta bersama pada umumnya disesuaikan kesepakatan para pihak, jika masingmasing dari suami istri memang mempunyai andil di dalam pengadaan barang yang telah menjadi milik bersama, biasanya ini terjadi jika suami dan istri sama-sama bekerja.

Berdasarkan ketentuan Pasal 37 UU No. 1 Tahun 1974 joPasal 126 dan 128 KUHPerdata, perceraian mengakibatkan bubarnya harta bersama sehingga harta bersama tersebut harus dibagi diantara pasangan suami-istri. Pembagian harta bersama sebaiknya dilakukan secara adil, agar tidak menimbulkan perselisihan antara harta suami dan isteri.Pasal $88 \mathrm{KHI}$ menyebutkan bahwa, apabila terjadi perselisihan antara suami istri tentang harta bersama, maka penyelesaian perselisihan itu diajukan kepadaPengadilan Agama.Pasangan suami-istri yang telah bercerai tidak selalu memperebutkan harta bersama, dengan beberapa pertimbangan sebagai berikut:

a. Mereka tidak bersengketa atau tidak mempermasalahkan harta bersamanya. Dalam hal ini biasanya kedua belah pihak bersepakat atau untuk membagi harta bersama secara kekeluargaan di luar siding.

b. Ada pula kedua belah pihak bersepakat agar harta bersama itu tidak dibagi kepada suami isteri yang bercerai tetapi dengan persetujuan bersama diberikan kepada anak-anaknya;

c. Ada pula antara para pihak itu yang tidak mempermasalahkan harta bersama yang penting cerai.

\section{B. KETENTUAN HUKUMPERKAWINAN CAMPURAN DAN AKIBAT HUKUMNYA}

1. Ketentuan Hukum Perkawinan Campuran 
Syarat

Pelangsungan

Perkawinan Campuran dan Pencatatan Perkawinan Campuran Perkawinan campuran dapat dilangsungkan di luar Indonesia (luar negeri) dan dapat pula dilangsungkan di Indonesia. Apabila dilangsungkan di luar negeri maka perkawinan tersebut sah bilamana perkawinan tersebut menurut hukum negara yang berlaku menurut di negara mana perkawinan itu dilangsungkan dan bagi Warga Negara Indonesia tidak melanggar ketentuan Undang-Undang Pokok Perkawinan (Pasal 56 ). Apabila dilangsungkan di Indonesia, perkawinan campuran dilakukan menurut UndangUndang Perkawinan ini (Pasal 59 Ayat (2)). Mengenai syarat-syarat untuk melangsungkan perkawinan harus dipenuhi syarat-syarat perkawinan materiil yang berlaku menurut hokum masing-masing pihak (Pasal 60 Ayat (1) ). Pejabat yang berwenang memberikan keterangan tentang telah dipenuhi syarat-syarat perkawinan menurut hukum yang berlakubagi masing-masing pihak ialah pegawai pencatat menurut hukum masing-masing pihak(Pasal 60 Ayat (2)).

Apabila pejabat pencatat menolak memberikan surat keterangan itu, yang berkepentingan mengajukan permintaan kepada Pengadilan, dan Pengadilan memberikan keputusannya. Jika keputusan Pengadilan itu menyatakan bahwa penolakan itu tidak beralasan, maka keputusan Pengadilan itu menjadi pengganti surat keterangan tersebut (Pasal 60 Ayat (3)) dan Ayat (4) ).

Setelah surat keterangan atau keputusan Pengadilan diperoleh, maka perkawinan segera dilangsungkan. Pelangsungan perkawinan dilakukan menurut hukum masing-masing agama.Pelangsungan perkawinan dilakukan di hadapan pegawai pencatat. Tata cara ini menurut Undang-Undang Perkawinan, jika perkawinan dilangsungkan di Indonesia. Jika perkawinan dilangsungkan di negara pihak lainnya itu, maka berlakulah ketentuantata cara menurut hukum di negara yang bersangkutan (Pasal 56 Ayat (1) ). Ada kemungkinan setelah mereka memperoleh Surat Keterangan atau Putusan Pengadilan, perkawinan tidak segera mereka lakukan.Apabila perkawinan mereka tidak dilangsungkan dalam masa enam bulan sesudah keterangan atau putusan itu diberikan, maka surat keterangan atau putusan Pengadilan itu tidak mempunyai kekuatan lagi (Pasal60 ayat (5)).

Yang berhak dan berwenang mencatat perkawinan campuran adalah pegawai pencatat (Pasal 61 Ayat (1)). Pegawai pencatat yang berwenang bagi yang beragama Islam ialah Pegawai Pencatat Nikah (PPN) atau Pembantu Pegawai Pencatat Nikah Talak Cerai Rujuk (P3NTCR).Sedangkan bagi yang bukan beragama Islam ialah Pegawai Kantor Catatan Sipil.Apabila tanpa memperlihatkan lebih dahulu kepada pegawai pencatat surat keterangan atau keputusan pengganti keterangan, saat perkawinan campuran dilangsungkan, akan dikenakan sanksi hukum dengan hukuman kurungan selama-lamanya satu bulan (Pasal 61 Ayat( 2)).

Pegawai pencatat yang mencatat perkawinan, sedangkan ia mengetahui bahwa keterangan atau keputusan pengganti keterangan tidak ada, dihukum dengan hukuman kurunganselama-lamanya tiga bulan dan dihukum jabatan (Pasal 61 Ayat( 3)). Diikutinya sistem hukum adat oleh Undang-Undang No. 1 Tahun 1974 sebagai hukum nasional adalah sebagai konsekwensi dari politik hukum Indonesia yang telah menggariskan bahwa pembangunan hukum nasional haruslah berdasarkan hukum adat sebagai hukum kepribadian bangsa Indonesia yang berdasarkan pancasila. 
2. Akibat Hukum perkawinan Campuran Aturan hukum tentang kewarganegaraan Indonesia telah mengalami perubahan yang cukup signifikan dengan disahkannya UU No. 12 Tahun 2006 tentang Kewarganegaran Republik Indonesia. Undang -Undang yang baru ini menggantikan UU N0.62 Tahun 1958 yang sangat diskriminatif. UndangUndang Kewarganegaraan yang baru ini telah diberlakukan oleh Presiden sejak tanggal 1 Agustus 2006.

Dalam penjelasan undangundang kewarganegaraan yang baru disebutkan bahwa,Undang-Undang Nomor 62 Tahun 1958 secara filosofis, yuridis,dan sosiologis sudah tidak sesuai lagi dengan perkembangan masyarakat dan ketatanegararaan Republik Indonesia. Secara yuridis, landasan konstitusional pembentukan undangundang tersebut adalah Undang-undang Dasar Sementara 1950 yang sudah tidak berlaku lagi sejak Dekrit Presiden 5 Juli Tahun 1959 yang menyatakan kembali ke Undang-Undang Dasar 1945. Undang-Undang Dasar 1945 telah menjamin perlindungan terhadap HAM dan hak warga negara.Undang-undang tersebut sudah tidak sesuai dengan perkembangan masyarakat Indonesia sebagai bagian dari masyarakat Internasional dalam pergaulan global, yang menghormati adanya persamaan perlakuan dimata hukum dan keadilan Gender.

Peraturan tentang perundangundangantentang Kewarganegaraan yang baru memuat peraturan atau asasasas kewarganegaraan yang umum atau universal. Adapun asas-asas yang dianut dalam undang-undang ini adalah;

a. Asas ius Sanguinis, adalah asas yang menentukan kewarganegaraan seseorang berdasarkan keturunan bukan berdasarkan negara tempat kelahiran.

b. Asas Ius soli, secara terbatas adalah asas yang menentukan kewarganegaraan seseorang berdasarkan tempat kelahiran, yang diberlakukan terbatas bagi anak-anak sesuai dengan ketentuan yang diatur dalam undang-undang ini.

c. Asas kewarganegaraan tunggal adalah asas yang menentukan setiap orang harus memeliki satukewarganegaraan.

d. Asas kewarganegaraan ganda terbatas adalah peraturan yang menentukan bagi anak-anak yang berkewarganegaraan ganda sesuai dengan ketentuan yang diatur dalam undang-undang.

Kemudian bagi orang-orang yang melaksanakan perkawinan campuran bias mendapatkan kewarganegaran dari suami atau isterinya, dan dapat pula kehilangan kewarganegaraan menurut peraturan yang terdapat dalam Undangundang kewaganegaraan Republik Indonesia yang berlaku (Pasal 58 Undang-Undang perkawinan) Berdasarkan Pasal 19 UU No.12 tahun2006, Warga Negara Asing yang kawin secara sah dengan Warga Negara Indonesia dapat memperoleh kewarganegaraan Republik Indonesia dengan menyampaikan pernyataan atau permohonan untuk menjadi Warga Negara Indonesia di hadapan pejabat, pernyataan tersebut hanya dapat dilakukan apabila yang bersangkutan tersebut sudah menetap di wilayah Republik Indonesia paling lama 5 (lima) tahun berturut atau 10 (sepuluh) tahun tidak berturut. Selanjutnya Pasal 26 UU No.12 Tahun 2006, mengatur bahwa. Orang-orang baik pihak laki-laki maupun perempuan yang menikah dengan Warga Negara Asing dapat kehilangan kewarganegaraan Republik Indonesia jika menurut hukum, dia baik 
pihak laki-laki maupun perempuan mengikuti kewarganegaraan pasangannya sebagai akibat perkawinan tersebut. Jika ingin tetap menjadi Warga Negara Indonesia dapat mengajukan surat pernyataan mengenai keinginannya kepada pejabat atau perwakilan Republik Indonesia yang wilayahnya meliputi tempat tinggal perempuan atau laki-laki tersebut.

\section{Dasar Pertimbangan Hakim Majelis Hakim Terhadap Pembagian Harta Bersama Setelah Perceraian Dalam Putusan Perkara Nomor \\ 526/PDT/G/2012/PN.JKT.SEL}

1. Pertimbangan Hakim Berdasarkan Kepada Azas Kepastian Hukum, Azas Keadilan Dan Azas Kemanfaatan

Putusan hakim didalam pengadilan biasanya mengandung aspek kepastian hukum, keadilan dan kemanfaatan.Dalam penerapannya tidak mudah untuk menggabungkan ketiga aspek tersebut, terutama dalam penerapan aspek kepastian hukum dan keadilan biasanya saling bertentangan.

Hasil penelitian menunjukkan bahwa seorang hakim dalam memeriksa dan memutus perkara tidak selamanya terpaku pada satu asas saja.Kendala yang di hadapi hakim yang cenderung kepada kepastian hukum mengalami kebuntuan manakala ketentuanketentuan tertulis tidak dapat menjawab persoalan yang ada.Penekanan yang lebih cenderung kepada asas keadilan berarti harus mempertimbangkan hukum yang hidup di masyarakat, yang terdiri dari kebiasaan-kebiasaan dan ketentuan hukum yang tidak tertulis.Demikian juga halnya dengan hakim dalam mewujudkan penegakan hukum yang bercirikan keadilan, kepastian hukum dan kemanfaatan melalui peradilan.Kekuasaan kehakiman merupakan kekuasaan yang merdeka untuk menyelenggarakan peradilan guna menegakkan hukum dan keadilan.

\section{Analisis Putusan}

Perjanjian pranikah diatur dalam Undang-Undang Nomor 1 Tahun 1974 tentang Perkawinan, pada Pasal 29. Perjanjian pranikah harus disetujui dan ditandatangani oleh kedua belah pihak secara prinsip sukarela dan tanpa paksaan serta tekanan dari pihak manapun, sebab apabila salah satu pihak merasa dipaksa, karena mendapatkan suatu ancaman atau tekanan maka secara hukum perjanjian pranikah dinyatakan batal dan tidak memiliki kekuatan hukum mengikat.

Pada putusan Perkara Nomor : 526/PDT/G/2012/PN.JKT.SEL

menunjukkan bahwa (1) Pelaksanaan perjanjian pranikah melalui akta notaris yang berdasarkan Undang-Undang Nomor 1 Tahun 1974 tentang Perkawinan harus Tidak dilaksanakan dengan itikad baik oleh masing-masing pihak yang membuat perjanjian pranikah. (2) Permasalahan hukum terhadap perjanjian pranikah melalui akta notaris berdasarkan UndangUndang Nomor 1 Tahun 1974 tentang Perkawinan salah satunya adalah pelanggaran terhadap perjanjian pranikah. Undang-Undang Nomor 1 Tahun 1974 tentang Perkawinan adalah apabila perjanjian perkawinan tidak didaftarkan pada pegawai pencatatan perkawinan untuk suami-istri tetap mempunyai akibat hukum bagi kedua belah pihak, karena perjanjian tersebut tetap mengikat kepada kedua belah pihak, sedangkan untuk pihak ketiga, apabila perjanjian perkawinan tidak didaftarkan maka akibat hukumnya perjanjian perkawinan tersebut tidak mempunyai kekuatan hukum yang mengikat terhadap pihak ketiga. Gugatan di Pengadilan menuntut untuk Membatalkan Seluruh isi perjanjian Pra 
Nikah yang hanya menguntungkan pihak sitergugat Isi Perjanjian Pra Nikah Pasal 1 : Antara pihak pertama dan pihak kedua tidak ada persekutuan harta kekayaan, bak persekutuan harta menurut hukum maupun persekutuan pencampuran laba dan rugi serta pencampuran buah / hasil Masingmasing pihak tetap menjadi pemilik dari segala harta kekayaan yang dibawanya ke dalam perkawinan dan diperolehnya karena pewarisan,hibah, hibah wasiat atau dengan cara apapun selama perkawinan berlangsung demikian pula harta kekayaan yang diperolehnya dengan jalan perbungaan atau penukaran".

Seperti dijelaskan diatas rasa keadilan itu berbeda antara masingmasing orang, adil untuk seorang atau sebagian orang belum tentu adil menurut orang lain, maka tugas hakimlah untuk dapat memberikan rasa keadilan bagi setiap orang yang mengajukan perkara ke Pengadilan atau setidak mendekati rasa keadilan bagi semua orang, dan dalam Perkara Nomor: 526/PDT/G/2012/PN.JKT.SEL ini apa yang dirasakan adil oleh Penggugat belum tentu juga dirasakan adil oleh Tergugat.

Terhadap Penggugat dianggap majelis hakim bersikap adil apabila majelis hakim mengabulkan semua gugatan Penggugat sedangkan Tergugat menganggap putusan majelis hakim tersebut adil apabila semua tuntutan Tergugat dikabulkan oleh majelis hakim.Maka tidak mudah untuk memenuhi rasa keadilan kedua belah pihak.Maka menurut penulis disinilah perlu azas kepastian hukum, seluruh permasalahan harta bersama itu harus didasarkan kepada hukum dan undangundang yang berlaku.

\section{KESIMPULAN}

1. Ikatan perkawinan menjadikan adanya harta bersama antara suami istri, sebagaimana tertuang dalam undang-undang perkawinan pasal 35 ayat (1). Namun, bukan berarti dalam perkawinan yang diakui hanya harta bersama sebab berdasarkan KHI pasal 85, yang juga ditegaskan oleh Ahmad Rofiq dalam bukunya yang berjudul Hukum Islam Di Indonesia, dinyatakan bahwa "meskipun terdapat harta bersama dalam perkawinan itu, dimungkinkan adanya hak milik tentang harta pribadi"

2. Perjanjian pranikah diatur dalam Undang-Undang Nomor 1 Tahun 1974 tentang Perkawinan, pada Pasal 29. Perjanjian pranikah harus disetujui dan ditandatangani oleh kedua belah pihak secara prinsip sukarela dan tanpa paksaan serta tekanan dari pihak manapun, sebab apabila salah satu pihak merasa dipaksa, karena mendapatkan suatu ancaman atau tekanan maka secara hukum perjanjian pranikah dinyatakan batal dan tidak memiliki kekuatan hukum mengikat.

3. Harta bersama adalah harta benda yang diperoleh selama perkawinan, kecuali harta yang termasuk dalam harta asal. Berdasarkan ketentuan Pasal 1 huruf (f) KHI mengatakan bahwa, harta yang diperoleh sendiri maupun bersama selama perkawinan merupakan harta kekayaan dalam perkawinan, dan selanjutnya disebut sebagai harta bersama tanpa mempersoalkan terdaftar atau diperoleh atas nama siapapun, baik suami maupun istri.

4. Syarat Pelangsungan Perkawinan Campuran dan Pencatatan Perkawinan Campuran dapat dilangsungkan di luar Indonesia (luar negeri) dan dapat pula dilangsungkan di Indonesia.

5. Pada putusan Perkara Nomor : 526/PDT/G/2012/PN.JKT.SEL menunjukkan bahwa (1) Pelaksanaan 
perjanjian pranikah melalui akta notaris yang berdasarkan UndangUndang Nomor 1 Tahun 1974 tentang Perkawinan harus Tidak dilaksanakan dengan itikad baik oleh masing-masing pihak yang membuat perjanjian pranikah.

6. Dalam putusan ini hakim juga mempertimbangkan sesuai dengan azas keadilaan dan kemanfaatan. Mejelis hakim memberikan hak yang sama kepada Penggugat maupun Tergugat dan keputusan ini juga memberikan manfaat kepada kedua belah pihak agar perselisihan tersebut dapat diselesaikan.

\section{DAFTAR PUSTAKA}

\section{Buku}

C.S.T Kansil, 1995, Modul Hukum Perdata, PT. Pradnya Paramita, Jakarta, 2007

Devita, Irma Purnamasari, 2012, KiatKiat Cerdas, Mudah dan Bijak Memahami Masalah Hukum Waris, Kaifa, Jakarta

Hartanto, Andy, Hukum Harta Kekayaan Perkawinan, Laksbang Grafika, Yogyakarta

Manan, Abdul, 2006, Aneka Masalah Hukum Perdata Islam di Indonesia, Kencana Prenada Media Grup, Jakarta

Muhammad, Abdulkadir, 1993, Hukum Perdata Indonesia.PT. Citra Aditya Bakti. Bandung

Pugung, Solahudin, 2011, Mendapatkan Hak Asuh Anak dan Harta Bersama di Pengadilan Agama, (Jakarta: Karya Gemilang
Pusat Pembinaan dan Pengembangan Bahasa Departemmen Pendidikan dan kebudayaan, 1995

Rofiq, Ahmad, 1997, "Hukum Islam Di Indonesia”, PT. Raja Grafindo Persada, Jakarta

Subekti, 2005, Pokok-Pokok Hukum Acara Perdata, PT. Intermasa, Jakarta

Syaifuddin, Muhammad \& Sri Turatmiyah dkk, 2012, Hukum Perceraian, Sinar Grafika, Jakarta

Triwulan, Titik dan Trianto, 2007, Perspektif, Perikatan Nikah, Prestasi Pustaka, Jakarta

Wignjodipoero , Soerodjo, Pengantar Dan Asas-Asas Hukum Adat, PT. Toko Gunung Agung, 1995, Jakarta

R. Purwoto S, 1998, Renungan Hukum, (Jakarta: Pengurus Pusat Ikatan Hakim Indonesia

\section{Peraturan Perundang-Undangan}

2006, Undang-Undang Perkawinan No. 1 Tahun 1974, Sinar grafika, Jakarta Kitab Undang-Undang Hukum Perdata (KUHPerdata)

Kompilasi Hukum Islam

\section{Website}

http://download.portalgaruda.org/artic le.php?article $=107609 \& \mathrm{val}=1003 \&$ title $=$ KEDUDUKAN-HARTABERSAMA-

DALAMPERKAWINANMENURUTPERSPEKTIFH UKUMISLM, diakses pada tanggal 17 April 2015 pada pukul 21.09 WIB. Universitas Sumatera Utara 